is basically an academic development, we can build on what has been achieved already, enabling family doctors of the future to become more fully prepared for their chosen career. Without it, without vocational training, we will find it difficult to maintain our present level.I am, etc.,

Penketh, Lancs.

TeViot EimerL.

SIR,-Many misunderstandings have crept into the correspondence. Before it closes may I help to clarify the issue? The real question is: Shall the College stiffen its criteria for entry to membership? What is proposed is that there shall be a further test for the younger potential member.

There is already a test for membership. Applicants, besides having to be registered an appropriate time, have to have two sponsors who are themselves members, and they may be interviewed by the College board of censors.

It is proposed that in future those who registered after 1961 , in addition to needing sponsors and being interviewed by the board, shall undergo a further test. No change in the criteria for membership is proposed for those who registered before 1961 - that is, those already established in practice.

The young potential entrant will have to show proof of satisfactory hospital experience and he will have to have had two years' experience in a general practice. In addition he will have to perform one of the three following tests: (1) submit a thesis or published work relevant to general practice, or (2) present reports of patients seen in general practice, or (3) pass an examination relevant to general practice.

It is hoped that (1) or (2) will be the commonly used methods and that (3), the "examination," will atrophy from disuse, so setting an example to our brethren in the other colleges.

There are complex reasons why the amendment of our constitution to stiffen the criteria for entry to membership has to be approved at three successive annual general meetings of the members of the College. It was so approved in 1961 and 1962. I hope that the A.G.M. of 1963 will finally confirm this decision.-I am, etc.

London W.12. Stuart Carne.

\section{Rickettsial Endocarditis}

SIR,-The clinicopathological conference reported in your recent issue (April 27, p. 1143) brings to a total of eight the reported cases of Q-fever endocarditis proved by a combination of serological tests, histological demonstration of rickettsiae in diseased heart valves, and isolation of $R$. burneti from the valves of all seven cases investigated for this purpose. ${ }^{123}$ The clinical features of these cases resemble closely those of rickettsial endocarditis following typhus reviewed by Worms ${ }^{4}$ - for example, an excess of males over females, predominant affection of the aortic valves, development of heart failure with nephritis and other visceral symptoms, obstructions of peripheral arteries, and increased gamma globulins. As in Q-fever endocarditis, blood cultures were usually negative, penicillin therapy ineffective, and the prognosis grave.

The uniformly fatal character, to date, of Q-fever endocarditis presents a challenge which is difficult to meet on the basis of the limited information available from the few cases yet recognized. It is therefore important that all cases of subacute infective endocarditis with repeatedly negative blood cultures should be tested for Q-fever antibodies. If the usual complement-fixation test with phase 2 antigen is positive, tests with phase 1 antigen may confirm the chronic nature of the infection. Since Dr. C. M. Fletcher informs me that case 246550 presented by him at the clinicopathological conference had both phase 1 and phase 2 antibodies, reactivity with phase 1 antigen has been found in seven of the reported cases, the single exception having had the unusually short duration of four months from onset to death. ${ }^{5}$ Full clinical and epidemiological histories of positive cases should be recorded, and in the event of death detailed necropsy should be carried out with full precautions against infection of staff. Where possible, isolation of rickettsiae from specimens of blood and urine may be attempted during life, and from heart valves and other tissues after death.

Though the studies of Marmion and colleagues ${ }^{6}$ and our own limited investigations in Glasgow do not suggest that Q-fever is a common cause of endocarditis in Britain, insufficient information is yet available to assess the frequency of this grave complication of an infection that is widespread throughout the country. ${ }^{7}$ Better understanding of the problem requires clinical awareness of the possibility of Q-fever as a cause of endocarditis and the collection of blood for the simple serological test which is appropriate.-I am, etc.,

University of Glasgow.

NoRMAN R. GRIST.

\section{REFERENCES}

Smith, W. G., and Evans, A. D., Lancet, 1960, 2, 846

Ferguson, I. C., Craik, J. E., and Grist, N. R., J. clin. Path., $1962,15,235$

Glick, L., Edwards, A. T. and Marmion, B. P. 1961 (cited by Marmion, B. P. J. Ḧy. E pidem. (Praha), 1962, 6, 79

Worms, R., Rev. Prat. (Paris), 1956, 6, 1309

Evans, A. D., Powell, D. E. B., and Burrell, C. D., Lancet, $1959,1,864$

Marmion, B. P., Higgins, F. E., Bridges, J. B., and Edwards, A. T., Brit. med. J., $1960,2,1264$.

A. and Stoker, M. G. P., Brit. med. J., 1958, 2, 809.

\section{Anaesthesia and Forceps Delivery}

SIR,-All obstetricians will agree with Mr. P. J. Huntingford (May 4, p. 1195) that local analgesia for forceps delivery carries less risk for the mother. What is not established, however, is that general anaesthesia carries an increased risk for the baby. It is true that the perinatal mortality is higher in forceps deliveries performed under general anaesthesia, but this is surely due to the fact that it is the more difficult forceps cases that are dealt with under general anaesthesia. One cannot compare the foetal results of forceps delivery under general anaesthesia and pudendal block, because the cases selected for each method are not comparable.

In St. Luke's Hospital, Bradford, in 1961 and 1962 there were 674 forceps deliveries, $9.8 \%$ of the total of 6,843 deliveries. Of the 674 , some $510(75.7 \%)$ were performed under pudendal block and 164 (24.3\%) under general anaesthesia. A total of 17 babies died:

\begin{tabular}{|c|c|c|}
\hline & Pud & ndal Block \\
\hline $\begin{array}{l}\text { Major congenital abnorma } \\
\text { Intrauterine death befor }\end{array}$ & ality $\ldots$ & 3 \\
\hline delivery commenced & $\begin{array}{l}\text { e forceps } \\
\ldots\end{array}$ & 4 \\
\hline $\begin{array}{l}\text { Prematurity } \ldots \\
\text { Intracranial haemorrhage }\end{array}$ & . & 1 \\
\hline Intracranial haemorrhage & . & 2 \\
\hline & Total & 10 \\
\hline
\end{tabular}

There is thus no suggestion that general anaesthesia per se contributes to perinatal mortality in babies delivered by forceps. There is an increased incidence of non-fatal neonatal asphyxia, but it has already been 
shown that this is related to the length of time which elapses between the start of the anaesthesia and the delivery of the baby. The high incidence of asphyxia in Mr. Huntingford's cases is presumably due to the long delay before the babies were delivered. (Just under half an hour in those cases receiving ether and about a quarter of an hour using the more rapid cyclopropane and thiopentone techniques.) When general anaesthesia is employed it is important to reduce this delay to a minimum compatible with safety, if neonatal asphyxia is to be avoided.

Transvaginal pudendal block ${ }^{2}$ is an extremely useful technique for many operative vaginal deliveries. The difficult forceps delivery, however, still calls for general anaesthesia. Provided this is skilfully given and delivery is not delayed, there should be no undue increase in neonatal asphyxia or in perinatal mortality. -I am, etc.,

St. Luke's Hospital, Bradford.

\section{J. M. BRudenell.}

REFERENCES

- Hamer-Hodges, R. J. (editors: T. Barnett and J. J. Foley.) The Obstetrician, Anaesthetist, and the Paediatrician in the Management of Obstetric Problems, 1963. Pergamon Press, London.

${ }^{2}$ Huntingford, P. J., J. Obstet. Gynaec. Brit. Emp., 1959, 66, 26.

\section{M.R.C. Report on Leukaemia}

SIR,-The first report to the Medical Research Council by the Working Party for the Evaluation of Different Methods of Therapy in Leukaemia was published in the Journal (January 5, p. 7). The subject was acute leukaemia in adults, and the report gave the results of a controlled clinical trial in which 6-mercaptopurine was administered alone or in combination with prednisone at either low or high dosage.

As part of the analysis of the fatality in the three groups of patients the deaths that occurred during the first four weeks from the start of treatment were related to the logarithm of the blast-cell count in the peripheral blood before treatment was begun. The analysis appeared to show that the patients with the higher blastcell count survived significantly better than those with the lower blast-cell counts. In the course of further work it has been found that the figures submitted as "blast-cell counts" were, in fact, blood neutrophil counts. The unusual relationship reported between the "blast-cell count" and fatality was, therefore, erroneous. The conclusions about the relative value of the different treatments are unaffected by this correction.-I am, etc.,

\section{A. G. Galton,}

Secretary, Working Party on the Evaluation of London S.W.3.

\section{General Practice Outmoded ?}

SiR,--Your leading article (May 11, p. 1245) quotes Professor J. H. F. Brotherston as stating that if things go on as they are the general practitioner will become a kind of medical social worker. It is my firm belief that the best general practitioners have always been just this. As soon as our medical schools can convince the admirably trained young men coming out of the medical schools that "social workers" is not a dirty word, comments like Professor Brotherston's will themselves become outmoded. Surely the general practitioner is the most versatile of the case workers rather than the least of the medical men ?-I am, etc.,

Bournemouth.

JAMES F. FISHER.
Renal Transplantation and the G.P.

SIR,-While the subject of renal transplantation and the status of general practitioners is so topical, I feel that I must bring the following case to your notice.

Recently a patient of mine was asked by a well-known hospital if she would be prepared to donate a kidney to a relative who was a patient of another doctor in another area. My patient was extensively investigated and was then admitted for the operation. Unfortunately, at that time the recipient's condition was not propitious and the operation was delayed for a fortnight. My patient was sent home with many instructions about how she should keep herself as free from infection as possible, but no advice about contacting her doctor. Eventually she was admitted. The operation was performed and then she was discharged. Only then, for the first time, did I hear from the hospital, telling me that she had been admitted, that the diagnosis was "renal donor," and that renal function tests were normal.

Some years ago this patient had a prolapsed urethra, which had been treated with pelvic exercises. Unfortunately, she forgot to mention this when she attended the hospital, and no vaginal examinations were made. Since her operation the prolapse has recurred, and she now has a severe urinary infection with albuminuria, haematuria, and $E$. coli partially resistant to the sulphonamides and tetracyclines.

In spite of Sir Arthur Thomson's statement, G.P.s still like to feel that they are of some importance, and had the hospital taken the trouble to write to me they would have learnt about the patient's prolapse, and this might have affected their decision to operate.-I am, etc.,

Edgware, Middlesex.

Gerald M. Michael.

\section{Buccal Smear Surveys for Sex Chromatin}

SIR,-The results of a survey of buccal smears for sex chromosome abnormalities by Sanderson and Stewart ${ }^{1}$ prompted a similar survey of the oligophrenic patients in the mental hospitals and hospitals for the mentally subnormal and the local authority training centres in Monmouthshire. Of 760 smears examined, 550 were male and 250 female, and patients showing abnormal smears were subjected to chromosome analysis (see Table).

\begin{tabular}{|c|c|c|c|c|c|}
\hline Sex & Age & $\begin{array}{c}\text { Sex } \\
\text { Chromosome } \\
\text { Constitution }\end{array}$ & $\begin{array}{l}\text { Chromo- } \\
\text { some } \\
\text { Number }\end{array}$ & $\begin{array}{c}\text { Physical } \\
\text { Characteristics }\end{array}$ & Diagnosis \\
\hline $\mathbf{M}$ & 19 & XXY & 47 & $\begin{array}{l}\text { Atrophic testes. Lack } \\
\text { of secondary sex } \\
\text { characteristics. I.Q. } \\
90\end{array}$ & $\begin{array}{r}\text { Klinefelter } \\
\text { syndrome }\end{array}$ \\
\hline $\mathbf{M}$ & ${ }^{35}$ & $\underset{\mathbf{X X Y}}{\mathbf{X X Y}}$ & $\begin{array}{l}47 \\
46 \\
47\end{array}$ & $\begin{array}{l}\text { As above. I.Q.42 } \\
\text { Kyphosis. Wedging } \\
\text { of vertebrae. Vari- }\end{array}$ & Mosäicism \\
\hline $\mathbf{M}$ & 70\{ & $\underset{\mathbf{X X X} X Y}{\mathbf{X X X}}$ & $\begin{array}{l}47 \\
49\end{array}$ & $\begin{array}{l}\text { cose ulcers. Chron- } \\
\text { ic bronchitis. I.Q. } \\
50\end{array}$ & \\
\hline $\mathbf{M}$ & 47 & XXYY & 48 & $\begin{array}{l}\text { Blind with corneal } \\
\text { opacities. White } \\
\text { hair. Feminine dis- } \\
\text { tribution of hair. } \\
\text { Atrophic testes. } \\
\text { I.Q.35 }\end{array}$ & \\
\hline $\mathbf{F}$ & 5 & $\mathbf{X X X X}$ & 48 & $\begin{array}{l}\text { Normal appearances. } \\
\text { Bilateral congenital } \\
\text { dislocation of hips } \\
\text { naevus left leg and } \\
\text { thigh. I.Q. } 40\end{array}$ & $\begin{array}{l}\text { Quadruple } \\
\text { X syn- } \\
\text { drome }\end{array}$ \\
\hline
\end{tabular}

This small survey has produced an unexpectedly interesting bag of sex chromosome abnormalities, particularly the last three cases. During some experimental work with a closed circuit television system it 